\title{
Exogenous determinants of entrepreneurial intuition and the mediatory role of psychological capital among potential youth entrepreneurs
}

\author{
Omonigho Simon Umukoro* and David Efevogho Okurame
}

\author{
* Correspondence: \\ simon.umukoro@yahoo.com \\ Department of Psychology, \\ University of Ibadan, P.O. Box, \\ 22400, U.I. Post Office, Ibadan, \\ Nigeria
}

\begin{abstract}
Some scholars have argued that intuition should be given more importance in scholarly research but not many researchers have investigated intuition in entrepreneurial settings. This study therefore investigated the influence of career adaptability, ambiguity tolerance, achievement need and mentoring support on entrepreneurial intuition and the mediatory role of psychological capital. The quantitative study employed an ex-post facto research design via cross-sectional survey among 1626 youth corps members across selected National Youth Service Corps (NYSC) orientation camps in Nigeria. Simple random sampling via a proportionate stratification technique was used to select youth corps members to participate in the study sample. Results showed that after controlling for the mediator (psychological capital), there was a decrease in the significant predictive value of career adaptability $(\beta=.142 ; p<.05)$ and mentoring support $(\beta=.063$; $p<.05)$ on entrepreneurial intuition; indicating partial mediation. However, the significant predictive value of need for achievement ( $\beta=.006 ; p>.05$ ) on entrepreneurial intuition was nullified; indicating full mediation. In a bid to enhance the intuitive capacity of potential entrepreneurs, it was recommended that intensive and comprehensive entrepreneurship training (which would include modules of career adaptability, need for achievement and mentoring support) should be incorporated in all categories of tertiary institutions.
\end{abstract}

\section{Background}

Entrepreneurship is an outcome of complex balancing of opportunity initiatives, risks and rewards. It is a process by which people pursue opportunities, fulfilling needs and wants through innovations, without regard to the resources they currently control. Through the process of entrepreneurship, it is possible to augment the scope of capital formation, job creation and facilitate industrialization in a country (Asaju, Arome \& Anyio, 2014). Entrepreneurship also acts as a powerful tool for raising productivity through innovation, facilitating transfer of technology, playing key role in commercializing new products, redistribution of wealth and income, earning foreign exchanges, promoting social welfare and the likes (Collins, Hanges \& Locke, 2004).

(c) The Author(s). 2017 Open Access This article is distributed under the terms of the Creative Commons Attribution 4.0 International License (http://creativecommons.org/licenses/by/4.0/), which permits unrestricted use, distribution, and reproduction in any medium, provided you give appropriate credit to the original author(s) and the source, provide a link to the Creative Commons license, and indicate if changes were made. 
However, while entrepreneurship may be deemed beneficial in areas of job creation, its success depends on the intuitive capacity of entrepreneurs to make business decisions under fast-paced and saturated market conditions. Theoretical inferences have identified roles of various psychological constructs on different types of entrepreneurship behavior. This study however attempts to establish an empirical basis for the influence of career adaptability, ambiguity tolerance, need for achievement and mentoring support on entrepreneurial intuition. This paper presents details of the study background, problem statement, research methods, findings and concluding remarks.

Entrepreneurial intuition is defined as an instinctive and instantaneous capacity to recognize and respond to business-related cues (Sadler-Smith \& Shefy, 2004). It describes a set of intrinsic traits that can prompt a disposition towards patterns of effective entrepreneurial activities. La Pira and Gillin, (2006) define entrepreneurial intuition as that part of entrepreneurial decision and action that is not based on reason or extrapolations, but is based, instead, on a feeling of rightness. Often the feeling of certainty is absolute-the intuition is experienced as beyond question or doubt-and the feeling can encompass positive emotions, such as optimism and excitement. Crossan, Lane and White (1999) argue that "entrepreneurial intuition ... relies less on the knowledge base of the individual, but rather, on their instinctive capacity to recognize gaps and to identify possibilities" (p. 436).

Scholars have suggested that the intuitive capacity of entrepreneurs helps them make effective business decisions under fast-paced and saturated market conditions (Mitchell, Friga, \& Mitchell, 2005). Many of today's successful entrepreneurs attribute their success to their intuition. For instance, Donald Trump, Bill Gates, Oprah Winfrey and Steve Jobs, who are world renowned and successful entrepreneurs, have attributed their success to entrepreneurial intuition amongst other factors (Mills, 2012). Moreover, McMullen and Shepherd (2006) found that managers who adopted intuitive decision making were more effective than their counterparts who adopted analytical decision making. Thus, the concept of intuition becomes relevant in the field of psychology and entrepreneurship. This implies that, the success of a potential entrepreneur is largely dependent on their entrepreneurial intuition which acts as foundational catalyst that may provoke personal initiatives towards entrepreneurship success.

Guided by Cognitive-Experiential Self-Theory (CEST) (Epstein, 2003; Epstein 2010; Epstein, Pacini, Denes-Raj \& Heider, 1996; Pacini \& Epstein, 1999) and by conceptual work on opportunity identification (Dimov, 2007), (Dutta and Crossan, 2005) suggest that intuition may be one of the cognitive processes responsible for enabling experienced entrepreneurs to leverage their vast knowledge and complex mental frameworks to enhance their opportunity identification ability. Intuitive processing, which involves the matching of environmental stimuli with some deeply held (subconscious) category, pattern or feature (Dane \& Pratt, 2007), is conceptualised in CEST as being experientially-derived and holistically-oriented (Epstein, 2003; Epstein 2010), and is argued to be crucial for opportunity identification. CEST has only recently been applied to the entrepreneurship field (e.g. Cerni, Curtis, \& Colmar, 2014). CEST assumes that all people, including entrepreneurs, process information by two bi-directional, interacting systems; that is, the rational (analytical) and experiential (intuitive) systems. The 
outcome of this processing is a major determinant of how they feel, interpret events, make decisions, and behave (Epstein, 2014).

Theoretical inferences have identified roles of various psychological constructs on different types of entrepreneurship behavior. This study however attempts to establish an empirical basis for the influence of career adaptability, ambiguity tolerance, need for achievement and mentoring support on entrepreneurial intuition. These psychological constructs have been touted to be correlates of implicit learning; which Lieberman (2000) suggests is the source of intuition. Career adaptability is defined as an individual's readiness to cope with unanticipated transitions in future career possibilities (Savickas, 2002); tolerance for ambiguity is defined as an individual's disposition towards decisions or events with vague outcomes (McLain, 2009); need for achievement is the extent of an individual's desire for significant accomplishment and high standards (Ogunleye \& Osagu, 2014); while mentoring support is defined as the extent of inspirational and motivational support that protégés have received from mentors on entrepreneurship issues (Okurame, 2012).

Literature has also shown that in every quest, an individual's goal directed activities are usually hinged on certain innate capacities that act as mediators in the exhibition of specific goal directed behavior. Combined, these capacities represent what has been termed psychological capital (Luthans, Youssef, Avolio, \& Norman 2007). This psychological capital has been defined as "an individual's positive psychological state of development and is characterized by: (1) having confidence (self-efficacy) to take on and put in the necessary effort to succeed at challenging tasks; (2) making a positive attribution (optimism) about succeeding now and in the future and (3) when beset by problems and adversity, persevering, sustaining and bouncing back (resilience) to attain success".

\section{Statement of problem}

Some scholars (Child, Elbanna \& Braga-Rodrigues, 2010; La Pira \& Gillin, 2006) have argued that intuition should be given more importance in scholarly research on entrepreneurship. However, not many researchers have taken up the challenge of empirically investigating intuition in entrepreneurial settings. There is therefore a gap in the academic literature concerning the role of intuition in entrepreneurship which has prompted appeals for scholarly attention. Moreover, some of the psychological constructs which have been touted to be linked with entrepreneurial intuition have been based on theoretical assumptions and have generated ambivalent outcomes. Outcomes of a pilot study on the relationship of various psychological variables with entrepreneurial intuition showed that the concepts of career adaptability, ambiguity tolerance, achievement need, mentoring support and psychological capital produced high inter-correlations with entrepreneurial intuition (Umukoro, 2016); yet literature on these variables as antecedents of entrepreneurial intuition is largely nonexistent. This study therefore attempts to address these shortcomings by adopting a quantitative approach in gaining empirical insight into the predictive role of career adaptability, ambiguity tolerance, achievement need and mentoring support on entrepreneurial intuition, while controlling for psychological capital as a mediator, among a catchment group of prospective entrepreneurs. The following hypothesis is therefore proffered.

Hi: The independent influence of the exogenous variables (career adaptability, tolerance for ambiguity, need for achievement and mentoring support) on entrepreneurial intuition would be mediated by psychological capital. 


\section{Methods}

The quantitative study employed a cross-sectional research design. The study was carried out among youth corps members in the six National Youth Service Corps (NYSC) orientation camps in south-western Nigeria. Apart from the fact that an NYSC orientation camp is made up of a culturally diverse set of Nigerian youths, the choice of this population was premised on the fact that this population forms a catchment group of nascent entrepreneurs in Nigeria. Adopting the Krejcie and Morgan (1970) sample size formula, a representative sample was obtained based on the expected total number of youth corps members deployed to each of the selected orientation camps (as obtained from the NYSC directorate headquarters). Simple random sampling via a proportionate stratification technique was used to select youth corps members to participate in the study sample. Based on the sample size distribution among the selected NYSC camps, a composite sample size of 1975 youth corps members was obtained for the study.

Summary Table of Sample Size Distribution for Selected NYSC Camps

\begin{tabular}{lllll}
\hline & State & NYSC Batch (2016) & Population & Sample Size \\
\hline 1 & Oyo & Batch A Stream I & 4,034 & 351 \\
2 & Lagos & Batch A Stream I & 4,868 & 354 \\
3 & Ogun & Batch A Stream I & 2,200 & 327 \\
4 & Ondo & Batch A Stream II & 1950 & 320 \\
5 & Osun & Batch A Stream II & 1650 & 310 \\
6 & Ekiti & Batch A Stream II & 1700 & 313 \\
\hline
\end{tabular}

A formal letter was written to the management of the NYSC requesting approval to conduct the research within the premises of the selected NYSC camps. Copies of a letter of introduction obtained from the Department of Psychology, University of Ibadan were also attached. Having obtained approval from the office of the NYSC Directorate Headquarters to conduct the research in each of the selected states, the researcher visited the selected NYSC orientation camps within the study area. The camp management was intimated about the study and implored to enlist the cooperation of personnel in charge of registration for incoming corps members. The process of questionnaire distribution was explained to the personnel in charge of camp registration provided by the camp management. Questionnaires were handed over to the registration personnel and they were then instructed to attach a questionnaire to every $n t h$ biodata form for the corps members during the registration process. Completed questionnaires were to be retrieved alongside the completed biodata forms and placed in paper bags which were provided by the researcher. The mobile detail of a contact person among the participating personnel was collected for communication access. All participating personnel were adequately compensated before commencement of the process.

A total of 1975 questionnaires were distributed. However, 1821 questionnaires were successfully retrieved, out of which 195 questionnaires were discarded due to incomplete and/or inappropriate responses. A total of 1626 completed questionnaires were used for the analysis. The fieldwork and data collection process spanned through the 2016 batch 'A' NYSC in the six orientation camps within the Southwest of Nigeria. 
Completed questionnaires coded into the SPSS software application. Multiple regression (path analysis) was used to test for mediation in the hypothesis using Baron and Kenny's (1986) four step approach in which several regression analyses are conducted and significance of the coefficients are examined at each step.

\section{Instrument}

A structured questionnaire was used to collect data for this study. The questionnaire was made up of validated scales that measured constructs of career adaptability, tolerance for ambiguity, need for achievement, mentoring support, psychological capital, and entrepreneurial intuition. The scales were pre-tested via a pilot study to validate its psychometric properties for the study population. Properties of the instruments are described below.

\section{Career adaptability}

Career adaptability was measured using Savickas' Career Adaptability Scale (2002). The scale is based on Savickas' (1997) model of Career adaptability which is conceptualised as an aggregate model, where choice readiness, planning, exploration, and confidence jointly produce career adaptability measure. All items are measured on a 5-point response format ranging from "1: strongly disagree" to "5: strongly agree". High scores depict higher levels of career adaptability while low scores depict lower levels of career adaptability. The scale has been validated in several studies (Hirschi, 2009; Koena, Klehe, Van Vianen, Zikic, \& Nauta, 2010) with Cronbach's alpha ranging from 0.6 to 0.8. In this study, a Cronbach alpha of 0.71 was obtained for the scale.

\section{Ambiguity tolerance}

Ambiguity tolerance was measured using The Multiple Stimulus Types Ambiguity Tolerance Scale-II (MSTAT-II; McLain, 2009). The MSTAT-II is a 13-item measure designed to measure an individual's cognitive tolerance range (aversion to attraction) for situations that are unfamiliar, insoluble, or complex. The MSTAT-II measures the participants' degree of ambiguity tolerance based on five stimulus types: Items are structured as five-point Likert-type responses ranging from " 1 : strongly disagree" to " 5 : strongly agree". Classification of participants into high ambiguity tolerance or low ambiguity tolerance is determined by a median split of total scores; scores ranging between 13 and 38 indicates a lower ambiguity tolerance while scores between 39 and 65 indicate a higher ambiguity tolerance. McLain (2009) reported an internal consistency reliability of .83 (Cronbach's alpha) which did not increase if any of the 13 items were eliminated. In this study, a Cronbach alpha of 0.79 was obtained for the scale.

\section{Need for achievement}

Need for achievement was measured using the Achievement Motive Scale (AMS-10; Lang \& Fries, 2006). The 10-item scale consists of 5 items to measure hope of success (HS) and 5 items to assess fear of failure (FF). Responses are structured on five-point Likert scale ranging from "1: strongly disagree" to "5: strongly agree". Concerning the reliability of the scales, it is typically found that the two scales for HS and FF show acceptable internal consistencies (Cronbach's alpha: 0.71 to 0.83 for HS and 0.81 to 
0.89 for FF; Lang \& Fries, 2006). In this study, a Cronbach alpha of 0.81 was obtained for the scale.

\section{Mentoring support}

Mentoring Support was measured using a modified version of a 15-item mentoring functions scale by Okurame (2012) The 15-item scale measures the extent of mentoring support that protégés feel they have received from their mentors in entrepreneurship issues using a response scale of 1 = "strongly disagree" to 5 = "strongly agree." Examples of some of the items in the modified version include "I have a mentor who gives me competent advice about handling business opportunities", 'I have a mentor whose entrepreneurship skills have influenced my desire to build similar skills'. An alpha coefficient of .89 was obtained by the original author of the scale. In this study, a Cronbach alpha of 0.95 was obtained for the scale.

\section{Psychological capital}

The psychological capital questionnaire (PCQ; Luthans, Youssef \& Avolio, 2007) was used to assess psychological capital. The PCQ draws from widely recognized published standardized measures for each of the positive constructs that make up PsyCap as follows: (1) hope (2) optimism (3) self-efficacy; and (4) resilience. The 12-item PCQ has responses put into a five-point Likert-type scale with categories ranging from 1 = strongly disagree to 5 = strongly agree. High scores depict higher levels of self-belief and personal drive towards future outcomes while low scores depict lower levels of selfbelief and personal drive towards future outcomes. The PCQ has demonstrated good internal consistency for the respective subscales (hope: 0.72, optimism: 0.74, self-efficacy: 0.75, and resilience: 0.71) on the samples utilised in Luthans, Avolio, Avey, \& Norman's (2007) study. In this study, a Cronbach alpha of 0.90 was obtained for the scale.

\section{Entrepreneurial intuition}

A culturally relevant entrepreneurial intuition scale developed by the researchers was used for the study. The scale comprised of 21 items which measured intuitive dimensions of ingenuity (6 items), risk propensity (4 items), preemption (5 items) and opportunity recognition (6 items). A 5-point likert scale format ranging from 'Not True of Me =1' to 'Very True of $M e=5$ ' was adopted for this scale. A confirmatory factor analysis on the 21 items showed that all items loaded significantly on their constructs $(p<.001)$, with weights ranging from .51 to .83 . The reliability analysis of the entrepreneurial intuition scale produced a Cronbach alpha of 0.85 .

\section{Participants}

The study participants comprised of 780 (48\%) male corps members and 846 (52\%) female corps members. Their ages ranged from 19 years to 30 years old with 44 (2.7\%) of them being below 20 years old, 594 (36.5\%) of them being between 20 and 23 years old, $664(40.8 \%)$ of them being between 24 and 26 years old and 324 (19.9\%) of them being between 27 and 30 years old. Based on their individual tertiary alma maters, 692 (42.6\%) of the participants were from federal universities, $434(26.7 \%)$ of them were from state universities, 128 (7.9\%) of them were from federal polytechnics, 166 (10.2\%) 
of them were from state polytechnics while $206(12.7 \%)$ of them were from private tertiary institutions.

\section{Hypothesis testing}

Hypothesis of the study was tested using Baron and Kenny's (1986) four step multiple regression approach in which several regression analyses are conducted and significance of the coefficients are examined at each step as described;

Step 1: Conduct a simple regression analysis with $\mathrm{X}$ predicting $\mathrm{Y}$

Step 2: Conduct a simple regression analysis with $X$ predicting $M$

Step 3: Conduct a simple regression analysis with $M$ predicting $Y$

Step 4: Conduct a multiple regression analysis with $\mathrm{X}$ and $\mathrm{M}$ predicting $\mathrm{Y}$

Where $X$ represents the independent variables

$Y$ represents the dependent variable

$M$ represents the mediating variable

Step one: $Y=B_{O}+B_{1} X+e$

Results from Table 1 show that the exogenous variables (career adaptability, tolerance for ambiguity, need for achievement and mentoring support) jointly predicted entrepreneurial intuition among youth corps members $\left[\mathrm{F}_{(4,1615)}=84.68, \mathrm{R}^{2}=.174 ; p<.01\right]$ and accounted for $17.4 \%$ of the variance in entrepreneurial intuition. Further results on the independent prediction of the exogenous variables on entrepreneurial intuition suggest that career adaptability $(\beta=.239 ; p<.01)$, need for achievement $(\beta=.146 ; \mathrm{p}<.01)$ and mentoring support $(\beta=.177 ; p<.01)$ emerged as significant independent positive predictors of entrepreneurial intuition among youth corps members while tolerance for ambiguity did not significantly predict entrepreneurial intuition among youth corps members. The results from Table 1 indicates that the first condition for mediation is supported.

Step two: $M=B_{0}+B_{1} X+e$

Results from Table 2 show that the exogenous variables (career adaptability, tolerance for ambiguity, need for achievement and mentoring support) jointly predicted psychological capital (the mediating variable) among youth corps members $\left[\mathrm{F}_{(4,1617)}=285.74, \mathrm{R}^{2}=.415 ; p<.01\right]$ and accounted for $41.5 \%$ of the variance in psychological capital. Further results on the independent prediction of the exogenous variables on psychological capital suggest that career adaptability $(\beta=.246 ; \mathrm{p}<.01)$, need for achievement $(\beta=.354 ; \mathrm{p}<.01)$ and mentoring support $(\beta=.285 ; \mathrm{p}<.01)$ emerged as significant independent positive predictors of psychological capital among youth corps members while tolerance for ambiguity $(\beta=-.059 ; \mathrm{p}<.05)$ emerged as a significant

Table 1 Multiple Regression Summary Table Showing Predictive Influence of Exogenous Variables On Entrepreneurial Intuition

\begin{tabular}{|c|c|c|c|c|c|c|c|}
\hline & $R$ & $R^{2}$ & $\mathrm{~F}$ & Sig & $\beta$ & $\mathrm{t}$ & $p$ \\
\hline Career Adaptability & & & & & .239 & 9.423 & $<.01$ \\
\hline Ambiguity Tolerance & .417 & .174 & 84.68 & .000 & -.020 & -.855 & $>.05$ \\
\hline Need for Achievement & & & & & .146 & 5.804 & $<.01$ \\
\hline Mentoring Support & & & & & .177 & 7.256 & $<.01$ \\
\hline
\end{tabular}


Table 2 Multiple Regression Summary Table Showing Predictive Influence of Exogenous Variables on Psychological Capital

\begin{tabular}{|c|c|c|c|c|c|c|c|}
\hline & $\mathrm{R}$ & $R^{2}$ & $\mathrm{~F}$ & $P$ & $\beta$ & $\mathrm{t}$ & $p$ \\
\hline Career Adaptability & & & & & .246 & 11.481 & $<.01$ \\
\hline Ambiguity Tolerance & .644 & .415 & 285.740 & $<.01$ & -.059 & -2.954 & $<.01$ \\
\hline Need for Achievement & & & & & .354 & 16.772 & $<.01$ \\
\hline Mentoring Support & & & & & .285 & 13.871 & $<.01$ \\
\hline
\end{tabular}

independent negative predictor of psychological capital among youth corps members. The results from Table 2 indicate that the second condition for mediation is supported.

Step three: $Y=B_{O}+B_{1} M+e$

Results from Table 3 shows that psychological capital emerged as a significant predictor of entrepreneurial intuition $(\beta=.490, p<.01)$ and accounted for about $24 \%$ in the variance of entrepreneurial intuition among youth corps members. The results from Table 3 indicate that the third condition for mediation is supported. Results from Steps 1-3 establish that zero-order relationships among the study variables exist, therefore mediation may exist.

Step four: $Y=B_{O}+B_{1} M+B_{2} M+e$

Results from Table 4 show that the exogenous variables (career adaptability, tolerance for ambiguity, need for achievement and mentoring support) and psychological capital jointly predicted entrepreneurial intuition among youth corps members $\left[\mathrm{F}_{(5,1613)}=114.67, \mathrm{R}^{2}=.263 ; p<.01\right]$ and accounted for $26.3 \%$ of the variance in entrepreneurial intuition. Further results on the independent prediction of the exogenous variables and psychological capital on entrepreneurial intuition suggest that career adaptability $(\beta=.142 ; \mathrm{p}<.01)$, mentoring support $(\beta=.006 ; \mathrm{p}<.01)$ and psychological capital $(\beta=.393 ; \mathrm{p}<.01)$ emerged as significant independent positive predictors of entrepreneurial intuition among youth corps members while tolerance for ambiguity $(\beta=.004 ; \mathrm{p}>.05)$ and need for achievement $(\beta=.006$; $p>.05)$ did not significantly predict entrepreneurial intuition among youth corps members. To confirm the impact of psychological capital as a mediator between the exogenous variables (career adaptability, tolerance for ambiguity, need for achievement and mentoring support) and entrepreneurial intuition, the beta $(\beta)$ weights and $p$-value of the exogenous variables in Step 1 and Step 4 of the model were compared. Results are presented in Table 5.

An examination of the comparative analysis of results from Step 1 and Step 4 shows that the predictive value of career adaptability on entrepreneurial intuition decreased $\left(\beta_{1}=.239, \beta_{2}=.142\right)$ after controlling for the mediator; consistent with partial mediation. Similarly, the predictive value of mentoring support on entrepreneurial intuition decreased $\left(\beta_{1}=.177, \beta_{2}=.063\right)$ after controlling for the mediator; consistent with partial mediation. However, need for achievement was no longer a significant predictor of entrepreneurial intuition after controlling for the mediator $\left(\beta_{1}=.146\right.$,

Table 3 Multiple Regression Summary Table Showing Predictive Influence of Psychological Capital on Entrepreneurial Intuition

\begin{tabular}{llllllll}
\hline & $R$ & $R^{2}$ & $F$ & $P$ & $\beta$ & $t$ & $P$ \\
\hline Psychological Capital & .490 & .240 & 511.614 & $<.01$ & .490 & 22.619 & $<.01$ \\
\hline
\end{tabular}


Table 4 Multiple Regression Summary Table Showing Predictive Influence of Exogenous Variables and Psychological Capital on Entrepreneurial Intuition

\begin{tabular}{|c|c|c|c|c|c|c|c|}
\hline & R & $R^{2}$ & $\mathrm{~F}$ & $P$ & $\beta$ & $\mathrm{t}$ & $\mathrm{p}$ \\
\hline Career Adaptability & & & & & .142 & 5.695 & $<.01$ \\
\hline Ambiguity Tolerance & & & & & .004 & .197 & $>.05$ \\
\hline Need for Achievement & .513 & .263 & 114.673 & $<.01$ & .006 & .238 & $>.05$ \\
\hline Mentoring Support & & & & & .063 & 2.585 & $<.01$ \\
\hline Psychological Capital & & & & & .393 & 14.039 & $<.01$ \\
\hline
\end{tabular}

$\left.\beta_{2}=.006\right)$; consistent with full mediation. The path coefficients of the exogenous variables and psychological capital were established by obtaining the differences in $\beta$ weights of the variables in Step 1 and Step 4 of the model. Results are presented in Table 6.

Table 6 shows the direct path coefficients (beta) which is a standardized regression coefficient for all the variables. It indicates the direction, strength and significance level of the exogenous variables (career adaptability, tolerance for ambiguity, need for achievement and mentoring support) and the mediating variable (psychological capital) on entrepreneurial intuition. The empirical model for this study is highlighted in Fig. 1.

\section{Results and Discussion}

The study hypothesis stated that the independent influence of the exogenous variables (career adaptability, tolerance for ambiguity, need for achievement and mentoring support) on entrepreneurial intuition would be mediated by psychological capital. The results supported the hypothesis by identifying the significant influence of career adaptability, need for achievement and mentoring support on entrepreneurial intuition as well as the significant mediatory effect of psychological capital. The justification for the impact of career adaptability on entrepreneurial intuition stems from its role in enhancing an individual's readiness and resources for coping with transitions in current and anticipated tasks. Thus, rather than prescribing a fixed process or measuring a particular outcome, it focuses on the individual's ability to adopt intuitive measures to survive and thrive in the business world. Similarly, need for achievement (N-Ach) which describes an individual's desire for significant accomplishment, mastering of skills, control, or high standards - may spur feelings of intuitive certitude over instantaneous business decisions. This need is influenced by internal drive for action and the pressure exerted by the expectations of others. Mentoring affords the transfer of implicitly learned skills and knowledge which protégés can access instinctively and

Table 5 Summary Table Showing Comparison of $\beta$ weights in Step 1 and Step 4 of the model

\begin{tabular}{llllll}
\hline & Step 1 & & Step 4 & \\
\cline { 2 - 3 } & $\beta$ & & & $\beta$ & \\
\hline Career Adaptability & .239 & $<.01$ & & .142 & $<.01$ \\
Ambiguity Tolerance & -.020 & $>.05$ & & .004 & $>.05$ \\
Need for Achievement & .146 & $<.01$ & .006 & $>.05$ \\
Mentoring Support & .177 & $<.05$ & & .063 & $<.05$ \\
Psychological Capital (Mediator) & & & .393 & $<.01$ \\
\hline
\end{tabular}


Table 6 Path coefficients of direct effect of exogenous variables on entrepreneurial intuition

\begin{tabular}{lll}
\hline Path & Variables & Path Coefficients \\
\hline A & Career Adaptability & $.097^{* *}$ \\
B & Ambiguity Tolerance & 016 \\
C & Need for Achievement & .140 \\
$D$ & Mentoring Support & $.114^{*}$ \\
\hline NB: $^{* *}=p<.01 ;{ }^{*}=p<.05$ & &
\end{tabular}

apply in diverse entrepreneurial decision making circumstances to foster success in entrepreneurship ventures.

Moreover, the plausibility of these results is supported by similar findings across the entrepreneurship literature. For instance, Brimrose, Brown, Barnes and Hughes (2011) examined the role of career adaptability in skills supply for entrepreneurship and found that career adaptability had significant influence on success trends among entrepreneurs. Creed, Fallon and Hood's (2009) study demonstrated that the career adaptability variables were inter-related and predicted entrepreneurial success. Wu, Matthews and Dagher (2007) investigated whether need for achievement has an effect on persistence behavior among nascent entrepreneurs. Their results found that Nach positively influenced entrepreneurial persistence. Audet and Couteret (2012) examined the effectiveness of mentorship as a support measure for young entrepreneurs and found that young entrepreneurs with mentor entrepreneurs were relatively more successful than young entrepreneurs without mentor entrepreneurs Furthermore, the justification of psychological capital as a mediator between the exogenous variables of this study and entrepreneurial intuition is highlighted in the fact that an individual's goal directed activities are usually hinged on certain innate capacities that act as mediators in the exhibition of specific goal directed behavior. Luthans, Youssef and Avolio, (2007) assert the combination of these capacities represent what has been termed psychological capital.

The plausibility of psychological capital being a mediator to entrepreneurial intuition can be illustrated in instances where individuals having the required certification in

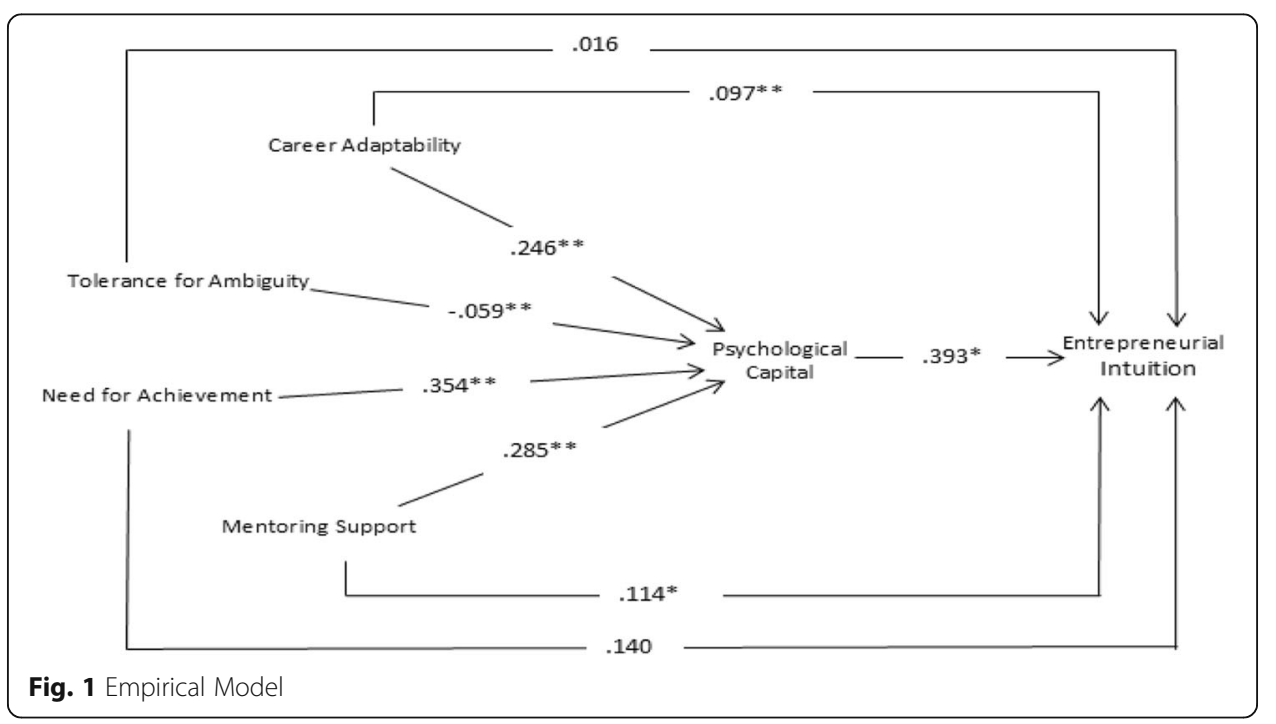


business administration, backed up with adequate financial capital still fail in business ventures, or do not even venture into business at all. Thus, success in business ventures also entails individuals to have confidence (self-efficacy) to take on and put in the necessary effort to succeed in the business; making a positive attribution (in form of optimism and hope) about succeeding in the business and; when beset by problems and adversity in the business, the ability to persevere, sustain and bounce back (resilience) to attain business success.

In line with the outcomes of this study, Dhammika and Roche (2010) carried out a study of 4 entrepreneurs, in order to ascertain the potential contribution of psychological capital, for entrepreneurs, during a recession. Results showed that the four dimensions of psychological capital enhanced entrepreneur's ability to manage during the recession. Moreover, those entrepreneurs who demonstrated psychological capital before the recession were better able to buffer the impacts of the recession. Similarly Baluku, Kikooma and Kibanja (2016) explored the interaction between entrepreneurs' positive psychological capital and startup capital in leading to entrepreneurial success. Their results showed that optimism was the component of psychological capital that significantly moderated the relationship between startup capital and entrepreneurial success. Both startup capital and psychological capital emerged as significant predictors of entrepreneurial success; however, psychological capital was the better predictor.

\section{Conclusion}

Individuals who are entrepreneurially intuitive are expected to be successful in entrepreneurship ventures. Thus, the results of the study identify the importance of career adaptability, ambiguity tolerance and mentoring support on entrepreneurial intuition. The outcomes of this study further point to a nexus between the economics and the psychology of entrepreneurship. While there is a general belief that the success of a business venture is premised on the 'economics' of the business proposal, this study provides insight into the importance of the 'psychology' of the business proposer. The results of this study therefore imply that the absence of career adaptability, ambiguity tolerance and mentoring support among nascent entrepreneurs may result in business failure. Based on these results, it is recommended that intensive and comprehensive entrepreneurship training should be incorporated in all categories of tertiary institutions. Furthermore, such training should include modules of career adaptability, need for achievement and mentoring support alongside other important psychological constructs that promote success in entrepreneurship.

\section{Limitations and future directions}

This study is not without its limitations, the first of which is the use of self-report measures to obtain relevant data from the participants of the study. Self-reports are problematic as many people are more concerned with social desirability than with truth. As such data obtained through self-report measures are susceptible to the bias of social desirability.

The use of questionnaires through a cross-sectional survey design to measure a subconscious process such as entrepreneurial intuition may be substituted by an experimental 
design in which sub-conscious processes of entrepreneurial intuition may be objectively observed instead of subjectively reported. This could be achieved by evaluating participants' reactions to scenarios/simulations of business related challenges.

Further studies should also be replicated among out-of school youths without formal tertiary education experience in order to provide a basis for comparison between both categories of Nigerian youths. The outcomes of such studies may provide important implications for formulation and implementation of entrepreneurship policies for literate, semi-literate and illiterate youths in the society.

\section{Funding}

The research was self-funded through the institutional platform of the University of Ibadan as part of the requirements for a Ph.D in Industrial and Organizational Psychology.

\section{Authors' contributions}

OSU (Researcher) carried out the fieldwork, data analysis and write-up for the research. DEO (Academic Supervisor) developed and provided the 'mentoring support scale' used to obtain data for the study, carried out supervisory role for the research. Both authors read and approved the final manuscript.

\section{Competing interests}

The authors declare that they have no competing interests.

\section{Publisher's Note}

Springer Nature remains neutral with regard to jurisdictional claims in published maps and institutional affiliations.

Received: 4 May 2017 Accepted: 29 August 2017

Published online: 08 September 2017

\section{References}

Asaju, K., Arome, S., \& Anyio, S. (2014). The rising rate of unemployment in Nigeria the socio-economic and political implications. Global Business and Economic Research Journal, 3(2), 12-32.

Audet, J., \& Couteret, P. (2012). Coaching the entrepreneur: Features and success factors. Journal of Small Business and Enterprise Development, 19(3), 515-531.

Baluku, M. M., Kikooma, J. F., \& Kibanja, G. M. (2016). Psychological capital and the startup capital-entrepreneurial success relationship. Journal of Small Business \& Entrepreneurship, 28(1), 27-54.

Baron, R. M., \& Kenny, D. A. (1986). The moderator-mediator variable distinction in social psychological research: Conceptual, strategic, and statistical considerations. Journal of Personality and Social Psychology, 51, 1173-1182.

Bimrose, J., Brown, A., Barnes, S-A. \& Hughes, D. (2011) 'The role of career adaptability in skills supply', Wath-upon-Dearne, London: UK Commission for Employment and Skills, Evidence report 35. Main report

Cerni, T., Curtis, G., \& Colmar, S. (2014). Cognitive-experiential. Leadership model: How leaders' information-processing systems can influence leadership styles. Journal of Leadership Studies, 8(3), 26-39.

Child, J., Elbanna, S. \& Rodrigues, S.B. (2010). The political aspects of strategic decision making. In P.C. Nutt \& D. Wilson (Eds.), The handbook of decision making, Chichester: Wiley.

Creed, P. A., Fallon, T., \& Hood, M. (2009). The relationship between career adaptability, person and situation variables, and career concerns in young adults. Journal of Vocational Behavior, 74(2), 219-229.

Collins, C. J., Hanges, P. J., \& Locke, E. A. (2004). The relationship of achievement motivation to entrepreneurial behavior: A meta-analysis. Human Performance, 17(1), 95-117.

Crossan, M. M., Lane, H. W., \& White, R. E. (1999). An organizational learning framework: From intuition to institution. Academy of Management Review, 24(3), 522-537.

Dane, E., \& Pratt, M. G. (2007). Exploring intuition and its role in managerial decision making. Academy of Management Review, 32(1), 33-54.

Dhammika, S., \& Roche, M. (2010). Contribution of psychological capital to entrepreneurs success during recessionary times. In SHAKE-UP: New Perspectives in Business Research and Education: New Zealand Applied Business Education Conference (NZABE). Conference held at Napier, New Zealand.

Dimov, D. (2007). Beyond the single-person, single-insight attribution in understanding entrepreneurial opportunities. Entrepreneurship Theory and Practice, 31(5), 713-731.

Dutta, D. K., \& Crossan, M. (2005). The nature of entrepreneurial opportunities: Understanding the process using the 4 organizational learning framework. Entrepreneurship Theory and Practice, 29(4), 425-449.

Epstein, R. A. (2014). Neural systems for visual scene recognition. In M. Bar \& K. Keveraga (Eds.), Scene Vision (pp. 105-134). Cambridge MA: MIT Press.

Epstein, S., \& Pacini, R. (1999). Some basic issues regarding dual-process theories from the perspective of cognitive-experiential self-theory. In S. Chaiken \& Y. Trope (Eds.), Dual-process theories in social psychology. New York: Guilford Publishers.

Epstein, S. (2003). Cognitive-experiential self-theory of personality. In T. Millon \& M. J. Lerner (Eds.), Handbook of psychology, personality and social psychology (Vol. 5, pp. 159-184). NJ: John Wiley and sons Inc..

Epstein, S. (2010). Demystifying intuition: What it is, what it does, and how it does it. Psychological Inquiry, 21(4), $295-312$.

Epstein, S., Pacini, R., Denes-Raj, V., \& Heider, H. (1996). Individual differences in intuitive-experiential and analytical-rational thinking styles. Journal of Personality and Social Psychology, 71(2), 390-405. 
Hirschi, A. (2009). Career adaptability development in adolescence: Multiple predictors and effect on sense of power and life satisfaction. Journal of Vocational Behavior, 74, 145-155.

Koena, J., Klehe, U. C., Van Vianen, A. E. M., Zikic, J., \& Nauta, A. (2010). Job-search strategies and reemployment quality. The impact of career adaptability. Journal of Vocational Behavior, 77, 126-139.

Krejcie, R. V., \& Morgan, D. W. (1970). Determining sample size for research activities. Educational and psychological measurement. 30 607-610.

La Pira, F., \& Gillin, L. M. (2006). Non local intuition and the performance of repeat entrepreneurs. International Journal of Entrepreneurship \& Small Business, 3(1), p 17-35.

Lang, J. W. B., \& Fries, S. (2006). A revised 10-item version of the achievement. Motives scale: Psychometric properties in German-speaking samples. European Journal of Psychological Assessment, 22(3), 216-224

Lieberman, M. (2000). Intuition: A social cognitive neuroscience approach. Psychological Bulletin, 126(1), 109-137.

Luthans, F., Avolio, B. J., Avey, J.B.; \& Norman, S. M. (2007) Positive Psychological Capital: Measurement and Relationship with Performance and Satisfaction, Leadership Institute Faculty Publications. 11.

McLain, D. L. (2009). Evidence of the properties of an ambiguity tolerance measure: The multiple stimulus types ambiguity tolerance scale-II. Psychological Reports, 105, 975-988.

McMullen, J. S., \& Shepherd, D. A. (2006). Entrepreneurial action and the role of uncertainty in the theory of the entrepreneur. Academy of Management Review, 31(1), 132-152.

Mills K. (2012) Invisible Genius; The Intuition Secrets of the World's Greatest Leaders and How to Profit from Them. Imaginicity publishers

Mitchell, J. R., Friga, P. N., \& Mitchell, R. K. (2005). Untangling the intuition mess: Intuition as a construct in entrepreneurship research. Entrepreneurship Theory and Practice, 29(6) 653-679.

Ogunleye, A. J., \& Osagu, J. C. (2014). Self-efficacy, tolerance for ambiguity and need for achievement as predictors of entrepreneurial orientation among entrepreneurs in Ekiti state, Nigeria. European Journal of Business and Management, 6(17), 240-250.

Okurame, D. E. (2012). Linking work-family conflict to career commitment: The moderating role of gender and mentoring. Journal of Career Development., 39(5), 423-442.

Sadler-Smith, E., \& Shefy, E. (2004). The intuitive executive: Understanding and applying 'gut feel' in decision-making. Academy of Management The Executive, 18(4), 76-91.

Savickas, M. L. (1997). Constructivist career counseling: Models and methods. Advances in personal construct. Psychology, 4(2), 149-182.

Savickas, M. L. (2002). Career construction: A developmental theory of vocational behavior. In D. Brown \& Associates (Eds.), Career choice and development (4th ed., pp. 149-205). San Francisco, CA: Jossey-Bass.

Umukoro O.S. (2016) Implicit Factors as Determinants of Entrepreneurial Intuition and the Mediatory Role of Psychological Capital among Youth Corps Members in Southwestern Nigeria. Unpublished Ph.D. thesis, Department of Psychology, University of Ibadan.

Wu, S., Matthews, M. L., \& Dagher, G. (2007). Need for achievement, business goals and nascent entrepreneurs persistence. Management Research News, 30(12), 928-941.

Submit your manuscript to a SpringerOpen ${ }^{\circ}$ journal and benefit from:

- Convenient online submission

- Rigorous peer review

Open access: articles freely available online

High visibility within the field

Retaining the copyright to your article

Submit your next manuscript at $>$ springeropen.com 